\title{
O PROJETO SCIELO (SCIENTIFIC ELECTRONIC LIBRARY ON LINE) E A VISIBILIDADE DA LITERATURA CIENTÍFICA "PERIFÉRICA"
}

A literatura científica da corrente principal (periódicos que estão indexados no Instituto para Informação Científica, ISI) não reflete adequadamente a comunidade de pesquisadores, nem a produtividade nacional de países em desenvolvimento. Penso que isso é uma assertiva sobre a qual a maioria dos cientistas de países em desenvolvimento concordaria, mesmo aqueles que normalmente publicam em periódicos da corrente principal. Vários estudos já foram feitos sobre esse tema mas uma ferramenta importante para medir a validade desta assertiva estava ainda faltando: uma base de dados dedicada à literatura científica excluída da literatura da corrente principal.

O Scielo foi criado em 1996 visando dois objetivos. Primeiro, permitir que resultados da produção científica brasileira se tornassem mais visíveis internacionalmente. Segundo, construir uma base de dados que provesse indicadores que permitissem avaliar a produção nacional de conhecimento. O número de artigos na base de dados Scielo aumentou significativamente ao longo dos anos, principalmente por causa do número crescente de periódicos cobertos por esta base, que chega agora a 96. A base de dados possui mais de 20.000 artigos cujos textos completos podem ser acessados, dos quais $10 \%$ são contribuição de autores de outros países (79 países). Um fato interessante é que a maioria desses são artigos de autores estrangeiros sem colaboração com cientistas brasileiros. Esta tendência aumentou ao longo dos anos e aponta para o crescente interesse de autores de outros países em publicar em periódicos indexados no Scielo. Particularmente para autores latino americanos, os periódicos da base Scielo abrem um espaço editorial significativo. O uso do "site" também nos dá uma idéia de quanto os artigos do Scielo se tornaram mais visíveis, tanto no Brasil como em outros países: a transferência de informação aumentou exponencialmente atingindo 75 milhões de visitas em 2002. Destes visitantes, $20 \%$ foram de outros países.

Recentemente Alonso e Juricic, da Universidade de Oxford, publicaram um artigo curto na Nature (vol. 415, p. 471, 2002) no qual relatavam que 5 periódicos do Scielo que estiveram pelo menos 2 anos na base de dados Scielo e 5 anos na base de dados ISI tiveram seus fatores de impacto ISI mais do que dobrados. Os autores não mencionam o nome de periódicos, mas uma pesquisa que fiz revelou que um deles é Química Nova.

Um segundo propósito da base Scielo foi medir quanto os autores de periódicos do Scielo se citavam. Em outras palavras, há um fluxo de informação ("conversa científica") medido por citações e que é invisível à literatura da corrente principal? Contratamos para isso um serviço especial do ISI: quantificar citações na base ISI para todos periódicos do Scielo e não só para aqueles que estão na base ISI (vinte periódicos). Foi interessante notar que, para alguns periódicos as citações ISI eram mais numerosas que as citações Scielo, enquanto para outros era o contrário. Os 5066 artigos de Scielo do ano 2001 foram citados 6039 vezes por periódicos do ISI e 4725 vezes por periódicos do Scielo. Há alguma sobreposição de citações (citações de um artigo do Scielo por um periódico que pertence tanto a base Scielo quanto a ISI serão contadas duas vezes), mas esta deve ser baixa se comparamos o tamanho das duas bases de dados. Foi muito interessante notar a tendência de citações nas duas bases de dados. Nas áreas de Química, Biologia e Física, havia um número significativamente mais alto de citações ISI do que citações Scielo a periódicos de Scielo. Faz sentido desde que no Brasil, os investigadores destas áreas são tradicionalmente muito inclinados a publicar em periódicos da corrente principal, em parte devido a uma pressão de agências brasileiras de fomento à pesquisa. Nos casos de artigos de Medicina, Medicina Tropical e Saúde Pública há um equilíbrio, em termos de citações ISI e citações Scielo a periódicos do Scielo. Intencionalmente separei as áreas de Medicina Tropical e Saúde Pública pois nelas os pesquisadores geralmente lidam com temas mais relacionados a problemas nacionais de saúde; são também áreas vigorosas de ciência no Brasil. Os periódicos Memórias do Instituto Oswaldo Cruz, Revista do Instituto de Medicina Tropical e Revista de Saúde Pública são os mais citados na base Scielo por outros periódicos brasileiros. Estas citações representam um fluxo intenso de informação entre cientistas brasileiros que não pode ser capturado na base de ISI de dados. Finalmente, há duas áreas em que há mais citações de Scielo que citações de ISI: são as de Humanidades \& Ciências Sociais e Veterinária \& Agricultura. Aqui novamente os temas de estudo são muito mais dirigidos a interesses específicos do país. Principalmente no caso de Veterinário \& Agricultura, os periódicos brasileiros tem um papel importante em termos de disseminação de informação entre os cientistas. Creio que os líderes de agências de fomento à pesquisa no Brasil deveriam levar em conta a diferença entre áreas distintas quanto aos temas de estudo e aceitar que nem sempre um periódico da corrente principal é mais adequado para estabelecer uma "conversa científica".

No Brasil as áreas de Humanidades e Ciência Social têm um elo forte com a escola francesa. Nelas os autores são menos inclinados a estudos quantitativos e preferem publicar em anais de congressos ou em livros. O número de citações Scielo a periódicos nestas áreas representa apenas 10-20\% das citações totais nestas áreas. Isto nos faz refletir sobre um desafio: a importância de criar outros indicadores de produtividade e qualidade para estas áreas. Finalmente, gostaria de dizer algo sobre a qualidade do critério adotado por Scielo na seleção de periódicos brasileiros para sua base de dados. No ano 2001, dos 206 periódicos brasileiros citados na base Scielo, 84 eram periódicos de Scielo, os quais receberam 70,7\% das citações, e 122 eram periódicos fora da base Scielo, que foram responsáveis por $29,3 \%$ das citações. Estes indicadores claramente mostram que os periódicos Scielo são os mais citados entre os periódicos brasileiros, o que, numa certa extensão, tem a ver com a qualidade destes periódicos.

Em conclusão, os dados acumulados na base Scielo apontam para uma visibilidade internacional crescente de nossa literatura científica e um fluxo impressionante e até agora desconhecido de informações entre cientistas brasileiros de certas áreas. Outros países estão adotando a metodologia Scielo (acessar www.scielo.br). Talvez a cientometria moderna, quase exclusivamente baseada em dados do ISI, terá que reconsiderar seus paradigmas à medida que a base Scielo se torne mais robusta.

\author{
Rogerio Meneghini \\ Diretor do Centro de Biologia Molecular Estrutural \\ Laboratório Nacional de Radiação Sincrotron
}




\section{SCIELO (SCIENTIFIC ELECTRONIC LIBRARY ON LINE) PROJECT AND THE VISIBILITY OF "PERIPHERAL" SCIENTIFIC LITERATURE}

\begin{abstract}
The mainstream literature (journals that are in the Institute for Scientific Information, ISI, database) does not accurately reflect the population of researchers or the domestic productivity in less developed countries. I think that this is a statement that most of the scientists from developing countries would agree upon, even those that usually publish in mainstream journals. Several studies have already addressed this problem but an important tool to measure the validity of the statement
\end{abstract} above has been missing: a database devoted to scientific literature excluded from mainstream literature.

Scielo was created in 1996 to pursue two aims. First, to allow results of Brazilian knowledge production to become internationally more visible. Second, to construct a database to provide indicators that permit evaluation of domestic production of knowledge.

The number of articles in the Scielo database has increased significantly along the years, mainly because of the increasing number of journals covered by this database, which now number 96 . The database attained over 20,000 articles that can be accessed in full text, from which $10 \%$ are contributed by authors from other countries (79 countries). Interestingly, the majority of these are articles signed by authors from abroad, without collaboration with Brazilian scientists. This trend has increased over the years and points to the growing interest of authors from other countries in publishing in Scielo indexed journals. Particularly for Latin American authors, journals of the Scielo database have opened a significant editorial space. Site usage also gives us an idea of the tendency of Scielo articles to become more visible both in Brazil and abroad. The information transferred increased exponentially attaining 75 million visits in 2002. Visitors from abroad comprised $20 \%$.

Recently Alonso and Juricic, from Oxford University, published a letter in Nature (vol 415, p. 415, 2002) where they reported that 5 Scielo journals that have been at least 2 years in the Scielo database and 5 years in the Institute for Scientific Information (ISI) database more than doubled their ISI impact factor. The authors do not mention the journals name but a search that I did revealed that one of them is Quimica Nova.

A second purpose of the Scielo database was to measure how Scielo journal authors cited each other. In other words: is there a flow of information ("scientific conversation") measured by citations, that is invisible to mainstream journals? We ordered a special service from ISI to follow up the ISI citations database for all Scielo journals and not only for those that are in the ISI database (twenty). It was interesting to notice that for some journals ISI citations were higher than the Scielo citations while for others the Scielo citations were higher. As a whole, the 5066 articles from Scielo, year 2001, were cited 6039 times by ISI journals and 4725 times by Scielo journals. There is some overlap of citations (a citation from a Scielo article by a journal that is both in the Scielo and ISI databases will be counted twice), but it should be low if we compare the size of the two databases.
It was very interesting to notice the trend of citations in the two databases. In the areas of Chemistry, Biology and Physics, there was a significantly higher number of ISI citations than Scielo citations to Scielo journals. It makes sense since in Brazil investigators in these areas are traditionally very much inclined to publish in mainstream journals, in part due to a pressure from Brazilian funding agencies. Medicine and Tropical Medicine \& Public Health present a more equilibrated situation, in terms of ISI versus Scielo citations to Scielo Journals. I have intentionally separated these two areas because Tropical Medicine \& Public Health deal with topics that are more aimed at national problems of health. They constitute a vigorous area of science in Brazil. Memorias do Instituto Oswaldo Cruz, Revista do Instituto de Medicina Tropical and Revista de Saúde Pública are the most quoted Brazilian journals by other Brazilian journals. This represents an intense flow of information between Brazilian scientists, that cannot be captured at the ISI database.

Finally, there are two areas in which there are significantly more Scielo citations than ISI citations: Humanities \& Social Sciences and Veterinary \& Agriculture. Here again the subjects of study are very much directed to Brazilian specific interests. Mainly in the case of Veterinary \& Agriculture, the Brazilian journals play a great role in terms of dissemination of information among scientists. I think leaders of funding agencies in Brazil should notice the difference between different areas and accept that not always a mainstream journal is more adequate to establish a "scientific conversation".

Humanities and Social Science in Brazil have a strong link with the French school. They are less inclined to quantitative studies and prefer to publish in proceedings of congresses or books. The number of Scielo citations to journals in this area represents something like $10-20 \%$ of total citations. This makes us think about a challenge: the importance to create other indicators of productivity and quality for areas like this.

Finally, I would like to say something about the quality of the criteria adopted by Scielo in the selection of Brazilian journals for its database. In the Year 2001, from the 206 Brazilian journals cited, 84 were Scielo journals, responsible for $70.7 \%$ of the citations and 122 were non-Scielo journals, which were responsible for $29.3 \%$ of the citations. These indicators clearly show that the Scielo journals are the most cited among the Brazilian journals, what to a great extent has to do with the quality of these journals.

In conclusion, the data accumulated in the Scielo database point to an increasing visibility of our scientific literature across the world and an impressive and so far unknown flux of information among scientists of certain areas through Brazilian journals. Other countries are adopting Scielo methodology (see www.scielo.br). Maybe modern scientometrics, almost exclusively based on ISI data, will have to reconsider its paradigm as the Scielo database becomes more robust.

Rogerio Meneghini Director of the Center of Molecular Structural Biology National Laboratory of Synchrotron Radiation 